\title{
Revisit the Senate as it was meant to be - The Upper House was created to protect provincial interests in the federal legislative process
}

\section{Vincent Pouliot*}

The first selection of the Members of the Legislative Council shall be made, except as regards Prince Edward Island, from the Legislative Councils of the various Provinces, so far as a sufficient number be found qualified and willing to serve; such Members shall be appointed by the Crown at the recommendation of the General Executive Government, upon the nomination of the respective Local Governments, and in such nomination due regard shall be had to the claims of the Members of the Legislative Council of the Opposition in each Province, so that all political parties may as nearly as possible be fairly represented. ${ }^{1}$

- Fourteenth Resolution of the Quebec Conference, October 1864

The scandal provoked by the expense claims of individual senators has obscured a deeper malaise surrounding the Senate - one that dates back to Confederation. This malaise has to do with the reasons why the Fathers of Confederation established a Senate in the first place, and with their failure to follow through with a selection procedure that would have made it possible for the Senate to perform its intended function.

Montesquieu wrote of the British Constitution: "Political liberty is to be found only ... when there is no abuse of power. But constant experience shows us that every man invested with power is apt to abuse it, and to carry his authority as far as it will go .... To prevent this abuse, it is necessary from the very nature of things that power should be a check to power".

That is what the Senate was meant to be: a power that acts as a check to power. Specifically, it was to represent the check the provinces were given to hold those wielding federal powers accountable and to prevent their abuse of it.

Misconceptions regarding the constitution of the Senate have been upheld at every turn to become unquestioned truths. They serve those who would balk at being constrained by the will of Parliament in their exercise of the powers of the State. It is now dogma that the Senate represents the regional interests of Canada.

But a region is a geographical area. Geographical areas don't have interests! Only persons have interests. The "regions" of Canada who do possess wishes and interests were lawfully constituted into provinces and organised so that their residents could lawfully express the political will of those legal personalities through political parties in their respective legislatures. The Senate exists to protect the local and regional interests of the provinces within the federal legislative framework. 
The Senate must be able to advise the Governor General of the local and regional wishes and interests of the people if it is to play the role intended by confederation and established by the provisions of the Constitution. Section 18 of our Constitution ${ }^{3}$, as confirmed by section 4 of the Parliament of Canada Act, confers on both the Senate and the House of Commons the same powers and privileges as those belonging to the British House of Commons at the time of Confederation. ${ }^{4}$ This is so because the Senate was meant to be a representative institution, one as representative of our wishes and interests as the House of Commons in the federal Parliament of Canada.

Because Canada is a federation of provinces, the people's political will is divided regarding how they wish to govern themselves. While the constitution of the House of Commons represents our will to be governed in common throughout Canada, the Senate was created to represent and protect those purely local interests which the people want diversely governed by the provinces. Thus, section 22 of our Constitution states over and over that senators "shall represent" the provinces in the Parliament of Canada. ${ }^{5}$

It must be remembered that the Government of Canada acts in the name of the Crown, but derives its authority from the Canadian people. And both houses of our federal Parliament are needed for the people's political will to be fully expressed.

In their research for the Macdonald Royal Commission in the 1980s, Donald Smiley and Ronald Watts wrote:

The role and impact of a central chamber within a federal system is derived not only from its constitutional powers but also from the method of selection for its members and the composition of the chamber. Appointment by the central government is an arrangement unique to Canada. Elsewhere, this has generally been considered inappropriate if the members of the second chamber are to be genuine representatives of regional interests.... ${ }^{6}$

... The accepted reason for a second chamber in the Parliament of Canada is to protect provincial and regional interests. However, many believe that the Senate is inherently and irretrievably incapable of performing this role effectively because its members are appointed by the Governor-in-Council, in effect by the prime minister. ...

The $14^{\text {th }}$ Resolution of the 1864 Quebec Conference, which laid the groundwork for the Constitution of 1867, states that the Crown shall appoint the members of the Upper House "so that all political parties may as nearly as possible be fairly represented". ${ }^{8}$ It is clear that the Fathers of Confederation intended that the provincial political parties be fairly represented in the Senate. This resolution thus provides for the proportional representation of all provincial political parties in the Senate! In this way, the Senate would harmoniously reflect the local and regional wishes and interests of the people, as expressed in their provincial parliaments.

Despite the $14^{\text {th }}$ Quebec Resolution, a Senate selected in this way was nowhere specified in the text of the Constitution Act, 1867. However, section 32 does specify that the Governor General must fill a vacancy that arises in the Senate by appointing "a fit and qualified Person" (in French, "quelque personne capable et ayant les qualifications voulues"). ${ }^{9}$ Clearly, an appointee must be "fit" or "capable" to exercise the office of senator which, according to section 22, means to represent the provinces in Parliament. Both "fit" and "capable" mean more than possessing the abilities required to exercise the office of senator. They both require that senators possess the authority to act on behalf of the provinces they represent.

The Prime Minister of Canada can possess no more authority than what our representatives in the House of Commons may confide in him. We elect our federal MPs to represent and protect how we wish to govern ourselves in common throughout Canada. We elect our provincial representatives and vest them with the authority to represent and protect our local interests in the government of our province. The Prime Minister of Canada therefore cannot possess the authority to represent and protect the interests of the provinces. If the Prime Minister does not pos- 
sess this authority, then he cannot confide it so as to constitute a senator with the legal capacity to represent a province in the Senate; if the Prime Minister does not possess this authority, he or she does not possess the capacity to advise the Governor General regarding who would be "fit" to occupy the office of senator.

The representative character of the Senate was ensured by section 30 of the Constitution which specifically permits senators to resign. ${ }^{10}$ Within the context of the times, it was understood that if senators were made to feel that they no longer represented the wishes and interests of the authority to whom they owed their appointment, their sense of honour would oblige them to resign. Today, if provincial political parties selected senators, a party would require its choice of senator to sign an undated resignation guaranteeing that he or she maintains its confidence, and thus the authority to speak and act on its behalf and on behalf of its constituents.

The $14^{\text {th }}$ Resolution provided for only the first selection of senators to proportionally represent the provincial political parties because this was the extent to which the Fathers of Confederation could agree. A number of them argued that each province should be free to select their representatives as they best see fit. They would naturally have assumed that the representative principle underlying the first selection of senators would continue until their province determined otherwise. They certainly did not foresee that the federal government would be structured to exclude the provinces from advising the Governor General of their choice of representative.

However, from the time of Confederation to the present, those in power have feared the kind of check that an effective, representative Senate could provide. As a result, they have encouraged the misconceptions that have led to the mess we have today. The current crisis of the Senate provides an opportunity to consider returning to the original purpose and structure for Canada's Upper House that the Fathers of Confederation put forward in 1864.

\section{Notes}

* Vincent Pouliot is President of the Institute of Responsible Government, a Quebec City lawyer (retired) who has written extensively on constitutional issues, especially in regard to the Senate. He was an intervener in the 1997 Supreme Court of Canada Reference re: the Secession of Quebec, and from 1995 to 1997 he was the Leader of the Libertarian Party of Canada. An earlier version of this article appeared in Inroads Magazine Winter/Spring 2014.

1 The Quebec Resolutions, October 1864, resolution 14, online: <https://www.collectionscanada.gc.ca/ confederation/023001-7104-e.html>.

2 Montesquieu, The Spirit of Laws, translated by Thomas Nugent, 4th ed (London, UK: J. Nourse \& P. Vaillant, 1766) at 220.

3 Constitution Act, 1867 (UK), 30 \& 31 Vict, c3, s 18, reprinted in RSC 1985, Appendix II, No 5.

4 Parliament of Canada Act, RSC 1985, cP-1, s 4.

5 Constitution Act, 1867, s 22.

6 Canada, Royal Commission on the Economic Union and Development Prospects for Canada, Intrastate Federalism in Canada, by Donald R Smiley \& Ronald L Watts, vol 39 (Toronto: University of Toronto Press, 1985) at 55.

7 Ibid at 117-18.

8 Supra note 1 at resolution 14.

9 Supra note 3, s 32.

$10 \mathrm{Ibid}, \mathrm{s} 30$. 
